\title{
Influence of spray-drying process on properties of chitosan/xanthan gum polyelectrolyte complexes as carriers for oral delivery of ibuprofen
}

\author{
Ana Ćirić ${ }^{*}$, Jelena Milinković Budinčić ${ }^{2}$, Đorđe Medarević1, \\ Vladimir Dobričić ${ }^{3}$, Milena Rmandić ${ }^{4}$, Tanja Barudžija ${ }^{5}$, \\ Anđelija Malenović ${ }^{4}$, Lidija Petrović́ ${ }^{2}$ Ljiljana Đekić ${ }^{1}$
}

${ }^{1}$ University of Belgrade - Faculty of Pharmacy, Department of Pharmaceutical Technology and Cosmetology, Vojvode Stepe 450, 11221 Belgrade, Serbia

${ }^{2}$ University of Novi Sad - Faculty of Technology, Department of Biotechnology and

Pharmaceutical Engineering, Cara Lazara Boulevard 1, 21102 Novi Sad, Serbia

${ }^{3}$ University of Belgrade - Faculty of Pharmacy, Department of Pharmaceutical

Chemistry, Vojvode Stepe 450, 11221 Belgrade, Serbia

${ }^{4}$ University of Belgrade - Faculty of Pharmacy, Department of Drug Analysis, Vojvode Stepe 450, 11221 Belgrade, Serbia

${ }^{5}$ University of Belgrade, Vinča Institute of Nuclear Sciences, Laboratory for Theoretical Physics and Condensed Matter Physics, Mike Petrovića Alasa 12-14, 11351

Belgrade, Serbia

*Corresponding author: Ana Ćirić, e-mail: ana.ciric@pharmacy.bg.ac.rs

\begin{abstract}
Polyelectrolyte complexes (PECs) are attractive carriers with recognized potential to enhance oral delivery of poorly soluble high-dosed low-molecular-weight drugs. The formulation of solid oral dosage forms requires the drying of PECs, which may affect their physicochemical and biopharmaceutical properties. The aim of this study was to investigate the effect of spraydrying on the properties of ibuprofen-loaded chitosan/xanthan gum PECs and to assess the drug release kinetics from such PECs filled into hard capsules in comparison with corresponding PECs which are dried under ambient conditions. The yield, ibuprofen content, entrapment efficiency, and residual moisture content of spray-dried PECs were lower than those of ambient-dried PECs. Better flowability of spray-dried PECs was attributed to the almost spherical particle shape, shown by scanning electron microscopy. DSC and PXRD analysis confirmed the amorphization of ibuprofen during spray-drying. All the investigated PECs, obtained by drying under ambient conditions as well as by spray-drying, had high rehydration capacity both in $0.1 \mathrm{M}$ hydrochloric acid ( $\mathrm{pH}$ 1.2) and phosphate buffer $\mathrm{pH}$ 7.4. In vitro ibuprofen release from dried PECs was controlled during $12 \mathrm{~h}$ with the release of approximately $30 \%$ of entrapped ibuprofen. Spray-dried PECs provided better control of ibuprofen diffusion from the carrier compared to the ambientdried ones.
\end{abstract}

Keywords: chitosan, xanthan gum, ibuprofen, spray-drying, controlled drug release

doi.org/10.5937/arhfarm72-35133 


\section{Introduction}

In modern pharmacotherapy, there is a clear need for a simple and highly efficient system for the delivery of high-dosed drugs with limited solubility in gastrointestinal (GI) fluids (1). To achieve controlled (delayed or prolonged) drug release, the development of non-toxic, biocompatible, and well-tolerated drug carriers, such as polyelectrolyte complexes (PECs), is increasingly considered (2). PECs are polymer complexes formed by the establishment of ionic interactions between at least one polycation and one polyanion $(3,4)$. It has been shown so far that chitosan/xanthan gum-based PECs can be formed under different reaction conditions, dried by a variety of drying methods, and various active substances can be incorporated into them to ensure their controlled and/or site-specific release (5). Chitosan is a biocompatible, biodegradable, and mucoadhesive natural cationic polyelectrolyte, increasingly used in biomedicine, alone, or as a PECbased carrier (6). It consists of D-glucosamine and N-acetyl-D-glucosamine units linked by $\beta-(1-4)$ glycosidic bonds and may have varying degrees of deacetylation and molecular weight. Protonated amino groups of chitosan at $\mathrm{pH}$ values lower than 6.5 (pKa value of chitosan is about 6.5) can react with anionic groups of other polyelectrolytes and form PECs $(2,3)$. The use of chitosan in oral drug delivery systems for controlled release is limited, due to its rapid dissolution in the acidic environment of the stomach $(7,8)$. Xanthan gum is a natural anionic polysaccharide of bacterial origin. It forms rigid gels in interaction with suitable natural polycations such as chitosan (9). The basis of the structure of xanthan gum is a cellulose backbone with a side chain of trisaccharides consisting of two mannose units and glucuronic acid. The residues of pyruvic acid and glucuronic acid from the side chain make xanthan gum an anionic polyelectrolyte with pKa 3.1. Like chitosan, xanthan gum is a natural and biocompatible excipient $(9,10)$. Xanthan gum has a high molecular weight $\left(2 \cdot 10^{-6}-2 \cdot 10^{-7} \mathrm{~g} / \mathrm{mol}\right)$ and is suitable for the formation of gel networks that can be used as carriers of drugs or proteins (11). Due to its resistance to gastric acid, xanthan gum is used in combination with other polymers as an excipient in solid dosage forms to achieve controlled release of drugs (12). Also, xanthan gum can provide time-independent drug release kinetics (13). PECs of chitosan and xanthan gum are usually prepared by combining the aqueous dispersions of polymers $(10$, 14, 15). The formation of PECs is a consequence of mixing the aqueous solutions of polycation and polyanion and the establishment of electrostatic/ionic interaction between them. These interactions are strong but reversible and mostly depend on the degree of ionization and charge distribution in polyions. This can be easily influenced by the $\mathrm{pH}$ of the medium in which PEC is prepared (i.e., $\mathrm{pH}$ must be close to $\mathrm{pKa}$ values of both polyions to ensure that they are oppositely charged) (2). PECs are not new chemical entities, but can be considered entities with improved physicochemical and/or biopharmaceutical properties in comparison with polyions themselves (16). The formed bonds in PECs can be cleaved mostly by affecting the charge of polyions, especially by changes in $\mathrm{pH}(2,16)$. Various methods of drug entrapment can be performed to incorporate different active substances into PEC-based carriers. For example, Meka et al. (2) mentioned four ways for drug entrapment into PECs: (a) the active substance is 
present in the polymer (polycation or polyaion) solution, and entrapment occurs during the formation of the complex, (b) by absorption of the active substance from a solution with which the already prepared PEC comes into contact (suitable for porous materials or gels with sponge-like properties), (c) by chemically bonding the active substance to either polyanion or polycation or both, and (d) by employing the active substance as a partner in the formation of the PEC (usually requires at least one charge or polarizable group on the active substance). All methods mentioned above can be used for the entrapment of small molecules, while macromolecules can be incorporated either by premixing with the like-charged polyelectrolyte before the complexation or via adsorption on the surface of the already formed PEC (17). The obtained PEC dispersions can be subjected to various drying methods such as spray-drying (18), freeze-drying (lyophilization) (19), or can be oven-dried (20), and dried under ambient conditions (15). Different drying methods can produce PECs of different morphology, physicochemical and biopharmaceutical properties (21). Spray-drying is a well-known technique based on the evaporation of the solvent to convert the material from a liquid to a dried powder state by spraying a solution or suspension into a hot gaseous medium. During spray-drying, the solubility of the drug can be increased by converting the crystalline form to the amorphous one, which is useful for poorly soluble drugs. Moreover, this drying method is often used for the preparation of spherical particulate drug carriers with good flowability (22-24). The shape of particles can be easily defined by calculating their elongation ratio (ER) (length-to-width ratio). Some studies define particles with $\mathrm{ER}=1$ as perfectly spherical, with $1<\mathrm{ER}<1.15$ as spherical, and with ER $>1.15$ as non-spherical (15, 25-28). Various drying parameters, such as dispersion flow rate and inlet temperature, can be adjusted to obtain a product within defined characteristics and appropriate stability (29). This primarily refers to the potential improvement of the microbiological stability of spray-dried PECs, since a lower content of residual moisture can be expected in these complexes, due to the controlled drying conditions $(22,30)$. The spray-drying technique was used to prepare quercetinloaded chitosan/xanthan gum-based PEC to protect the encapsulated drug from adverse conditions in the stomach. The described carrier was suitable for colon-specific drug delivery (31).

Ibuprofen is a high-dosed non-selective reversible inhibitor of cyclooxygenase enzymes (COX-1 and COX-2) which are responsible for the production of prostaglandins ( $\mathrm{PGE}_{2}$ and $\mathrm{PGI}_{2}$ ) from arachidonic acid. It is one of the most commonly used drugs for the treatment of pain and inflammatory processes, and it is also recommended for the treatment of fever in children $(10,15)$. Due to its low solubility and high permeability (absolute bioavailability is about 100\%), ibuprofen is classified in class 2 of the Biopharmaceutical Classification System (BCS). Its short half-life (about $2 \mathrm{~h}$ ) implies the frequent use of dosage forms with immediate release of ibuprofen, so it is considered a suitable candidate for the formulation of controlled release oral preparations $(15,24,32)$. Our previous research (15) has shown that chitosan/xanthan gum-based PECs dried under ambient conditions were suitable carriers for ibuprofen entrapment and achieving its controlled release. The spray-drying process can also be used to prepare solid forms of 
ibuprofen-loaded chitosan/xanthan gum-based PECs. This drying method could be suitable for obtaining PECs with lower residual moisture content $(22,30)$, better flowability (22), and improved solubility and dissolution rate of entrapped ibuprofen (24, $33,34)$. Although numerous studies indicated the possibility of spray-drying of PECs of chitosan with different polyanions $(6,18,23,31)$, the literature does not list any studies that have dealt with spray-dried PECs based on chitosan and xanthan gum as ibuprofen carriers. Furthermore, the potential of spray-dried and ambient-dried chitosan/xanthan gum-based PECs to ensure the pH-dependent release of ibuprofen has not been investigated yet.

The aim of this study was to form chitosan/xanthan gum PECs with and without ibuprofen, investigate the effect of spray-drying on their physicochemical properties, as well as on the release kinetics of the entrapped ibuprofen, and compare these properties with the properties of ambient-dried PECs.

\section{Experimental section}

\section{Materials}

PECs were prepared using medium molecular weight chitosan (cationic polyelectrolyte) with a degree of deacetylation of 75-85\% (Sigma Aldrich, USA) and anionic polyelectrolyte xanthan gum (Jungbunzlauer, Switzerland). Ibuprofen (racemic) (BASF, Germany) was used as a model drug. The reagents used for the preparation of the polymer solutions and PECs, as well as for their characterization (purified water, acetic acid, sodium hydroxide, potassium dihydrogen phosphate, methanol, trifluoroacetic acid, and acetonitrile) (Ph. Eur. 10.0) were of HPLC grade and were used without additional purification.

\section{Methods}

\section{Preparation of chitosan and xanthan gum solutions and PEC dispersions}

The preparation of polymer solutions and PEC dispersions was carried out in accordance with the protocols described in our previous studies $(10,15)$. Aqueous solutions of chitosan $(0.65 \%)$ and xanthan gum $(0.65 \%)$ were prepared on the RZR 2020 propeller mixer (Heidolph, Germany) at $500 \mathrm{rpm}$. Acetic acid was used to adjust the $\mathrm{pH}$ of the chitosan solution to 4.6, and the $\mathrm{pH}$ values were measured on a $\mathrm{pH}$ meter HI 8417 (Hanna Instruments Inc., USA) at $20 \pm 2{ }^{\circ} \mathrm{C}$. The polymer solutions were stored at 2-8 ${ }^{\circ} \mathrm{C}$ (in a refrigerator) for $24 \mathrm{~h}$. The PEC dispersions were prepared at room temperature by mixing chitosan solution and xanthan gum solution to form placebo PEC or adding a dispersion of ibuprofen in xanthan gum solution (ibuprofen concentration in the dispersion was $0.975 \%$ ) into chitosan solution to form ibuprofen-loaded PEC. The weight ratio of chitosan and xanthan gum in PECs was 1:2, while the ratio of polymers and ibuprofen was 1:1. Mixing was performed on a RZR 2020 propeller mixer at $800 \mathrm{rpm}$. The PEC dispersions were stored at $2-8{ }^{\circ} \mathrm{C}$ for $24 \mathrm{~h}(10,15)$. 


\section{Drying of PECs}

The prepared PECs were dried using two different drying methods, spray-drying (SD) and ambient-drying (AD).

Prior to spray-drying, the PEC dispersions were subjected to rotor-stator homogenization (T25 digital Ultra-Turrax ${ }^{\circledR}$, IKA, Germany) for 5 min at $17500 \mathrm{rpm}$, as reported in the literature $(6,31)$. The homogenized dispersions of PECs (placebo and ibuprofen-loaded) were then spray-dried on a Mini Spray Dryer 190 (Büchi, Switzerland) using a $0.5 \mathrm{~mm}$ diameter nozzle, to obtain dry PECs in the form of powder. The inlet temperature of $140{ }^{\circ} \mathrm{C}$ was maintained, and the flow rate of PEC dispersions was 3 $\mathrm{ml} / \mathrm{min}$. Spray-dried PEC samples were labeled as P_SD (placebo PEC) and I_SD (ibuprofen-loaded PEC). The prepared samples were stored in a desiccator until further testing.

For ambient drying, thin layers of placebo PEC hydrogels and ibuprofen-loaded PEC hydrogels were poured into Petri dishes, in which they were dried to obtain dry films of constant mass. The films were then ground and sieved through a $355 \mu \mathrm{m}$ sieve $(\mathrm{Ph}$. Eur. 10.0) to obtain PECs in powder form. Grinding was performed using an electric kitchen mill, since the use of mortar and pestle did not result in obtaining particles of appropriate size. After grinding and sieving, the prepared samples were stored in a desiccator until further testing $(10,15)$. The prepared samples were labeled as P_AD (placebo PEC) and I_AD (ibuprofen-loaded PEC).

\section{Characterization of dried PECs}

\section{Determination of yield, entrapment efficiency and ibuprofen content in PECs}

After drying, the mass of dry placebo and ibuprofen-loaded PECs was measured on an analytical balance AE 240 (Sartorius, Germany) to determine the yield. The yield was calculated based on the known starting amounts of chitosan, xanthan gum, and ibuprofen used to prepare the PECs, which represented $100 \%$, and then these values were compared with the measured amounts of dry PECs (Eq. 1):

$$
\text { Yield }(\%)=\frac{\text { measured mass of PEC }}{\text { theoretical mass of PEC }} \cdot 100 \%
$$

To determine the entrapment efficiency (\%EE) and ibuprofen content, $10 \mathrm{mg}$ of a corresponding dry ibuprofen-loaded PEC was measured and dissolved in $10 \mathrm{ml}$ of a medium consisting of methanol and phosphate buffer $\mathrm{pH} 7.4$ in a volume ratio of 80:20 on a Sonorex RK1024 ultrasonic bath (Bandelin electronic, Germany), at $20 \pm 2{ }^{\circ} \mathrm{C}$ for 30 minutes, which led to the complete extraction, i.e., solubilization of the entrapped ibuprofen. The amount of ibuprofen in PECs was determined by the HPLC method on a Dionex Ultimate 3000 system (Thermo Fisher Scientific, Germany) equipped with a Dionex Ultimate 3000 quaternary pump, autosampler, DAD detector, and a Zorbax Extend C18 column $(150 \mathrm{~mm} \times 4.6 \mathrm{~mm}, 5 \mu \mathrm{m}$ particle size $)$. The mobile phase consisted 
of $0.05 \%$ trifluoroacetic acid and acetonitrile $(40: 60, \mathrm{v} / \mathrm{v})$. The column temperature was adjusted to $25{ }^{\circ} \mathrm{C}$ and the flow rate was $1 \mathrm{ml} / \mathrm{min}$. The detection of ibuprofen was performed at $254 \mathrm{~nm}$.

$\%$ EE was calculated using the following equation (Eq. 2):

$\% \mathrm{EE}=\frac{\text { real amount of ibuprofen in PEC }}{\text { theoretical amount of ibuprofen in PEC }} \cdot 100 \%$

The ibuprofen content was calculated using the following equation (Eq. 3):

Ibuprofen content $(\%)=\frac{\text { real amount of ibuprofen in PEC }}{\text { measured mass of PEC }} \cdot 100 \%$

For each sample, the measurement was repeated three times, and the results were presented as the mean $\pm \sigma$.

\section{Determination of residual moisture content of dry PECs}

The determination of residual moisture content was performed by the Karl-Fischer coulometric titration method on the $831 \mathrm{KF}$ coulometer (Metrohm, Switzerland). Hydranal-Coulomat AG (Fluka, Germany) was used as the titration reagent. Before titration, the method was validated. Measurements were performed in triplicate for each sample, and the results are presented as mean $\pm \sigma(15)$.

\section{Scanning electron microscopy (SEM)}

Prior to SEM analysis, the SCD 005 Cool Sputter Coater (Bal-Tec, Germany) was used to apply a thin conductive layer of gold on dry PECs. The micrographs were recorded in high vacuum $(5 \mathrm{kV})$ using a scanning electron microscope JSM-6390LV (JEOL, Japan) (10). The ImageJ software, version 1.52a (National Institutes of Health, USA) was used to evaluate the particle size and shape. One hundred particles were randomly selected from each sample and their dimensions were measured. The dimensions of spray-dried particles were expressed as mean diameter $\pm \sigma$, while the dimensions of ambient-dried particles were expressed as mean, maximum, and minimum of their length and width. The particle shape of dried PECs was estimated by calculating the elongation ratio (ER). ER represents the ratio of the length and the width of the particle (Eq. 4) (15):

$$
E R=\frac{\text { length }(\mu m)}{\text { width }(\mu m)}
$$

\section{Determination of powder flowability}

The powder flowability was determined using the indirect method, described in $\mathrm{Ph}$. Eur. 10.0, based on the calculated values of the Hausner ratio and the compressibility 
index (Carr index). Bulk $(\rho \mathrm{b})$ and tapped $(\rho \mathrm{t})$ density were calculated by pouring a known mass of dry PEC into a measuring cylinder $(\rho \mathrm{b})$, and then, after tapping the samples 1250 times $\left(\rho_{t}\right)$ on a StaV 2003 volumeter (J. Engelsmann AG, Germany). The Hausner ratio and the Carr index were calculated using the following equations (Eqs. 5 and 6):

$$
\begin{aligned}
& \text { Hausner ratio }=\frac{\rho_{t}}{\rho_{b}} \\
& \text { Carr index }=\frac{\rho_{t-\rho_{b}}}{\rho_{t}} \times 100
\end{aligned}
$$

\section{Differential scanning calorimetry (DSC) analysis}

All dry PECs were weighed and crimped into a standard aluminum pan $(40 \mu \mathrm{l})$ and then heated from $25{ }^{\circ} \mathrm{C}$ to $360{ }^{\circ} \mathrm{C}$ (heating rate $10{ }^{\circ} \mathrm{C} / \mathrm{min}$ ), under a constant nitrogen flow (50 $\mathrm{ml} / \mathrm{min}$ ) using the DSC 1 instrument (Mettler Toledo, Switzerland). The empty sealed pan was used as a reference $(10,15)$.

\section{Fourier-transform infrared spectroscopy (FT-IR) analysis}

The Nicolet iS10 FT-IR Spectrometer (Thermo Fisher Scientific, USA) was used to obtain the attenuated total reflectance FT-IR spectra of prepared dry PECs. The measurements were performed at a wavelength range between 4000 and $400 \mathrm{~cm}^{-1}$ (resolution 4, and 16 scans per sample) $(10,15)$.

\section{Powder X-ray diffraction (PXRD) analysis}

Bragg-Brentano $\theta-2 \theta$ geometry with the use of Ge-crystal primary monochromator (Johanson type) that generates $\mathrm{CuK} \alpha 1$ radiation $(\lambda=1.541 \AA$ ) was used to perform the PXRD analysis of dry PECs (Bruker D8 advance diffractometer, Bruker, Germany). The data was obtained in the $2 \theta$ range from 5 to $45^{\circ}$ (scan step $0.05^{\circ}$ and holding time of 12 s) $(10,15)$.

\section{Rheological characterization of dry PECs after rehydration}

The rehydration ability of placebo and ibuprofen-loaded PECs obtained by both drying methods was also examined. Dry PECs were used to make dispersions at a concentration of $2 \%$, on a laboratory shaker LSB18 Aqua Pro (Grant, UK) for $12 \mathrm{~h}$, at a temperature of $37 \pm 1{ }^{\circ} \mathrm{C}$ and $100 \mathrm{rpm}$ using $0.1 \mathrm{M}$ hydrochloric acid (pH 1.2) and phosphate buffer $\mathrm{pH} 7.4$ as rehydration media for each sample. Rheological measurements of the obtained dispersions were performed on a rotating and oscillatory rheometer Rheolab MC 120, with a measuring device Z3 DIN (25 mm). The tests were performed at a temperature of $37 \pm 0.2{ }^{\circ} \mathrm{C}$ at a controlled shear rate from $0 \mathrm{~s}^{-1}$ to $100 \mathrm{~s}^{-1}$, and then from $100 \mathrm{~s}^{-1}$ to $0 \mathrm{~s}^{-1}$. The duration of each phase was $400 \mathrm{~s}$. For each sample, the measurement was repeated three times, and the results were presented as mean $\pm \sigma$. 


\section{In vitro ibuprofen release testing}

Hypromellose hard capsules, size 0, (Fagron, Greece) were filled with dry ibuprofen-loaded PECs (spray-dried and ambient-dried) in an amount corresponding to $100 \mathrm{mg}$ of ibuprofen. The in vitro release rate of ibuprofen was tested on a rotating basket apparatus Erweka DT 600 (Erweka, Germany), at $37 \pm 1{ }^{\circ} \mathrm{C}$ and under stirring at 100 $\mathrm{rpm}$. The acceptor medium was $500 \mathrm{ml}$ of $0.1 \mathrm{M}$ hydrochloric acid (pH 1.2), during the first $3 \mathrm{~h}$, and $500 \mathrm{ml}$ of phosphate buffer $\mathrm{pH} 7.4$ (USP), from the $3^{\text {rd }}$ hour until the end of the assay. The sampling of $4 \mathrm{ml}$ of medium was performed after 15, 30, 45, 60, 90, 120 , $180,240,300,360,480,600$, and 720 minutes. Each sample was filtered through a 0.45 $\mu \mathrm{m}$ MF-Millipore ${ }^{\circledR}$ membrane filter. The ibuprofen concentration was determined using the previously described HPLC method. Mathematical models for zero (35), first-order (36) kinetics, as well as for Higuchi (37) and Korsmeyer-Peppas (38) kinetics were applied to the results. The data were processed using the DDSolver Excel Add-In (39).

In addition, the model-independent approach (40) was used to compare the drug dissolution rate profiles and similarity $\left(f_{2}\right)$ and difference $\left(f_{1}\right)$ factors were calculated using the DDSolver Excel Add-In.

\section{Results and discussion}

Dry ibuprofen-loaded PECs were white powders, while placebo PECs were pale yellow powders. Major differences between powders obtained by different drying methods were not noticed with the naked eye.

\section{Yield, entrapment efficiency, ibuprofen content and residual moisture content in dry PECs}

Table I shows the values of yield, \%EE, ibuprofen content, and residual moisture content of dry PECs. In comparison with ambient-dried PECs, significantly lower yields were observed in spray-dried samples, as well as \%EE and ibuprofen content in ibuprofen-loaded PECs obtained by spray-drying (I_SD). It can partially be the consequence of the homogenization of PEC dispersions prior to spray-drying and the potential disruption of the complex structure. In spray-dried samples, a higher yield was observed for placebo PEC (P_SD), while in ambient-dried samples higher yield was recorded for ibuprofen-loaded PEC (I_AD). The yield during spray-drying depended on the strength and extent of interactions within the complex. With an increase of these parameters, the yield decreased because higher forces were required to spray the sample. Considering the adhesion properties of chitosan, loss of fine particles due to their retention in the drying air cyclone and visually observed residual dust on the chamber surface may also have been the cause of lower yields $(18,41,42)$. The obtained yield and $\%$ EE values of spray-dried PECs were similar (18) or lower $(23,31,43)$ in comparison with the previously published results for chitosan-based PECs. When drying under ambient conditions, stronger interactions between polyelectrolytes led to lower losses during preparation, drying, and grinding, which resulted in higher yields, as previously reported (15). Grinding of ambient-dried PECs is expected to have a much lower impact 
on their structure and ibuprofen entrapment compared to homogenization and spraydrying. It is the last stage of preparation of ambient-dried PEC powders and the only one that can potentially affect the structure of the complex. The highest yield $(67.03 \pm 3.41 \%)$ and $\% \mathrm{EE}(61.52 \pm 3.12 \%)$ had I_AD, while ibuprofen content in that sample was 51.65 $\pm 1.66 \%$ which was expected, given that the mass ratio of polymers and ibuprofen during drug entrapment into PECs was 1:1. The \%EE value was similar to the yield value for ambient-dried PEC, so it can be concluded that the losses of chitosan, xanthan gum, and ibuprofen during preparation, drying, grinding and sieving were uniform (15). The moisture content was approximately $10 \%$ or lower in all samples, presumably due to the hygroscopicity of the polymers, primarily xanthan gum $(15,44)$. Also, the moisture content in ibuprofen-loaded PECs $(6.81 \pm 0.17 \%$ for I_AD and $4.96 \pm 0.09 \%$ for I_SD $)$ was lower than the moisture content in placebo PECs $(10.23 \pm 0.18 \%$ for P_AD and 8.60 $\pm 0.21 \%$ for P_SD), so this study confirmed that the drug entrapment into PECs may favor the microbiological stability of the carrier $(15,28)$. The spray-drying procedure resulted in a lower moisture content, probably due to constant and controlled drying conditions, temperature and air flow, which cannot be precisely adjusted in ambient-drying conditions $(15,45)$. As already mentioned, the high moisture content in PECs can lead to their lower physicochemical and microbiological stability (22).

Table I Yield, entrapment efficiency (\%EE), ibuprofen content and residual moisture content in spray-dried and ambient-dried placebo and ibuprofen-loaded PECs.

Tabela I Prinos, efikasnost inkorporiranja (\%EE), sadržaj ibuprofena i sadržaj rezidualne vlage placebo PEK i PEK sa ibuprofenom dobijenih sušenjem raspršivanjem i sušenjem pod ambijentalnim uslovima.

\begin{tabular}{ccccc}
\hline Sample & Yield $\pm \boldsymbol{\sigma}(\%)$ & $\boldsymbol{\%} \mathbf{E E} \pm \boldsymbol{\sigma}(\mathbf{\%})$ & $\begin{array}{c}\text { Ibuprofen content } \\
\pm \boldsymbol{\sigma}(\boldsymbol{\%})\end{array}$ & $\begin{array}{c}\text { Residual moisture } \\
\text { content } \pm \boldsymbol{\sigma}(\%)\end{array}$ \\
\hline P_SD & $27.18 \pm 7.66$ & N/A & N/A & $8.60 \pm 0.21$ \\
P_AD & $52.31 \pm 6.53$ & N/A & N/A & $10.23 \pm 0.19$ \\
I_SD & $20.59 \pm 0.11$ & $6.52 \pm 0.12$ & $17.47 \pm 0.28$ & $4.96 \pm 0.09$ \\
I_AD & $67.03 \pm 3.41$ & $61.52 \pm 3.12$ & $51.65 \pm 1.66$ & $6.81 \pm 0.17$ \\
\hline
\end{tabular}

\section{Scanning electron microscopy (SEM)}

Figure 1 shows micrographs of ambient-dried and spray-dried PECs, while Table II shows data on particle dimensions and shape. A significant difference in the shape and size of particles obtained by different drying methods was observed. Ambient-dried PECs had an irregular shape, mostly needle-shaped to quadrangular, as well as a wide size distribution. On the other hand, spray-dried PECs had an approximately spherical shape with a narrow size distribution, with characteristic surface "cavities" and irregularities, probably caused by the unequal extent and strength of the interactions in different parts 
of PECs (23). Different amounts of water were bound and evaporated during drying, so the 3D structure "collapsed" in those places. As previously described, the particle shape of the ambient-dried PECs was a consequence of the drying and grinding process of the samples $(10,15)$.
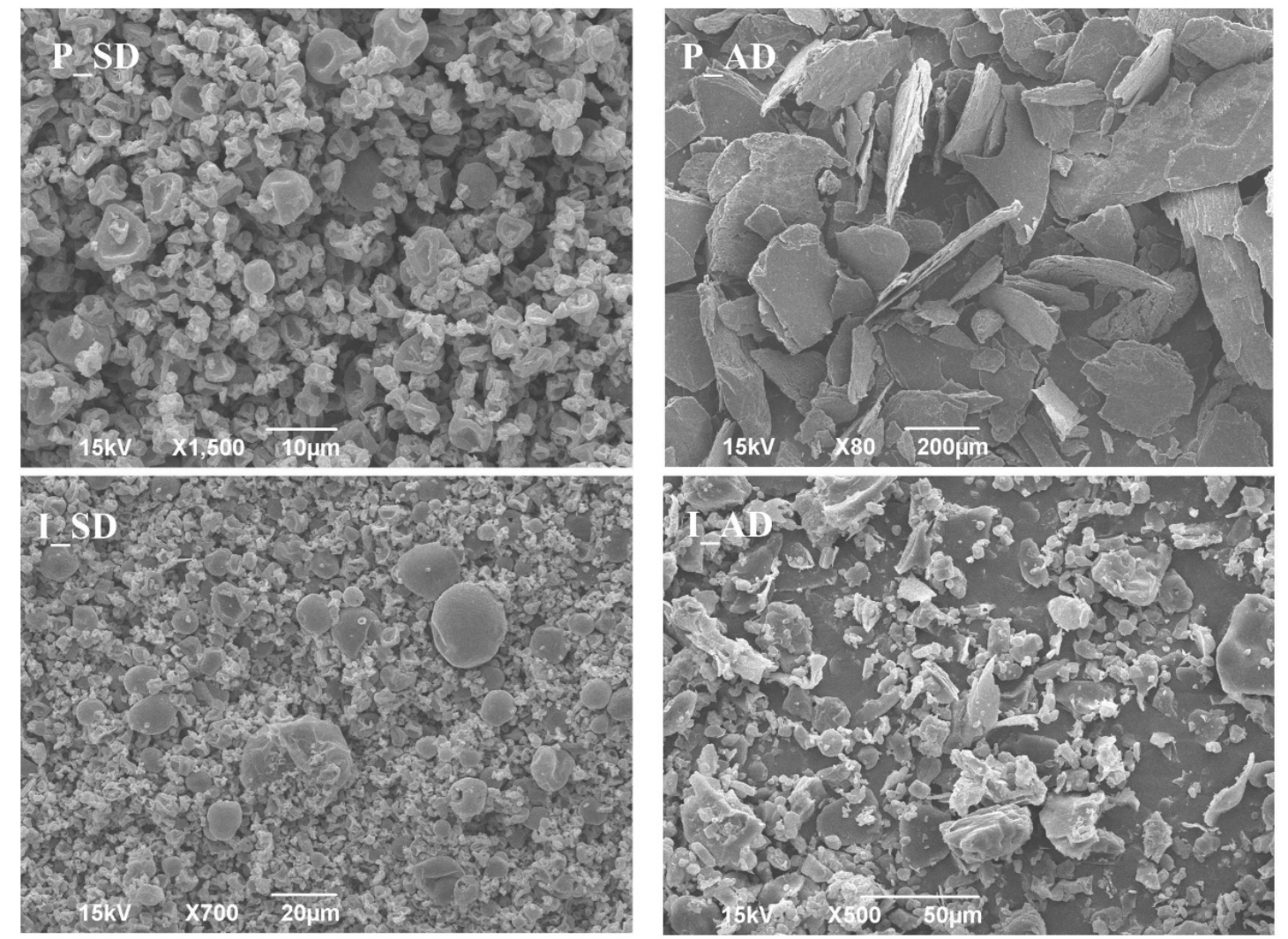

Figure 1. SEM micrographs of dry placebo and ibuprofen-loaded PECs obtained by spray-drying and ambient-drying.

Slika 1. SEM mikrografije suvih placebo PEK i PEK sa ibuprofenom dobijenih sušenjem raspršivanjem i sušenjem pod ambijentalim uslovima. 
Table II Dimensions and ER values of spray-dried and ambient-dried placebo and ibuprofenloaded PECs.

Tabela II Dimenzije i ER vrednosti placebo PEK i PEK sa ibuprofenom dobijenih sušenjem raspršivanjem i sušenjem pod ambijentalnim uslovima.

\begin{tabular}{|c|c|c|c|c|c|c|c|c|c|c|}
\hline \multirow{2}{*}{ Sample } & \multicolumn{3}{|c|}{ Length $(\mu \mathrm{m})$} & \multicolumn{3}{|c|}{ Width $(\mu \mathrm{m})$} & \multirow{2}{*}{$\begin{array}{c}\text { Diameter } \pm \sigma \\
(\mu \mathrm{m})\end{array}$} & \multicolumn{3}{|c|}{ ER } \\
\hline & mean & $\max$ & $\min$ & mean & $\max$ & $\min$ & & mean & $\max$ & $\min$ \\
\hline P_SD & N/A & N/A & N/A & N/A & N/A & N/A & $3.79 \pm 1.66$ & 1.15 & N/A & N/A \\
\hline P_AD & 178.29 & 342.83 & 18.58 & 79.87 & 205.22 & 9.03 & $\mathrm{~N} / \mathrm{A}$ & 2.23 & 1.67 & 2.06 \\
\hline I_SD & N/A & N/A & $\mathrm{N} / \mathrm{A}$ & N/A & N/A & N/A & $6.69 \pm 3.91$ & 1.12 & N/A & $\mathrm{N} / \mathrm{A}$ \\
\hline I_AD & 15.41 & 48.25 & 2.70 & 10.27 & 32.87 & 2.43 & N/A & 1.50 & 1.47 & 1.11 \\
\hline
\end{tabular}

In addition to differences in shape, significant differences in particle size of PECs obtained by different drying methods were observed. Due to differences in particle shape, the dimensions of ambient-dried PECs were expressed as length and width, and for spraydried PECs as particle mean diameter (Table II). Significantly different dimensions of placebo PEC and ibuprofen-loaded PEC were also observed in ambient-dried PECs. P_AD had a mean length of $178.29 \mu \mathrm{m}$, while the mean width was $79.87 \mu \mathrm{m}$. I_AD had significantly smaller particles and had a mean length of $15.41 \mu \mathrm{m}$ and a mean width of $10.27 \mu \mathrm{m}$. Table II also shows the minimum and maximum values of both parameters. Based on these data, ER values were calculated and confirmed the irregular shape of ambient-dried PECs (ER >1.15), whereas I_AD had a shape closer to spherical compared to P_AD. Ibuprofen-loaded PEC was more prone to grinding and the obtention of particles of more regular shape in comparison with placebo PEC due to the presence of a high amount of a small molecule (ibuprofen) in the structure of the complex. Obtained results for ambient-dried PECs are similar to those previously published $(10,15)$. PEC particles obtained by spray-drying were of almost spherical shape $(\mathrm{ER} \leq 1.15)$, significantly finer and had a more uniform size distribution, which can be explained by the existence of controlled drying conditions with this method (23). P_SD had a diameter of $3.79 \pm 1.66 \mu \mathrm{m}$, and I_SD of $6.69 \pm 3.91 \mu \mathrm{m}$. These results are similar to those shown by Caddeo et al. (31) and Budinčić et al. (45). A different trend in particle size of placebo and ibuprofen-loaded PEC depending on the drying method was noted. In ambient-dried PECs, P_AD had significantly larger particles in comparison with I_AD, which can be explained by the high extent of low molecular weight ibuprofen in samples and therefore their lower resistance to grinding, despite stronger interactions of polymers and drug within this complex, as previously mentioned. P_AD consisted only of high molecular weight polymers, so it was more resistant to grinding. On the other hand, in spray-dried PECs P_SD had slightly smaller particles in comparison with I_SD. Lower strength and extent of interactions between polymers in P_SD than in I_SD resulted in the easier spraying of this sample and smaller particles were obtained (23).

Table III shows the values of the Carr index and the Hausner ratio of dried PECs, as well as descriptive flow terms based on the obtained values. 
Table III Flowability of spray-dried and ambient-dried placebo and ibuprofen-loaded-PECs.

Tabela III Protočnost placebo PEK i PEK sa ibuprofenom dobijenih sušenjem raspršivanjem i sušenjem pod ambijentalnim uslovima.

\begin{tabular}{cccc}
\hline Sample & Carr index & Hausner ratio & Flowability \\
\hline P_SD & 21.50 & 1.27 & Passable \\
P_AD & 27.04 & 1.37 & Poor \\
I_SD & 22.94 & 1.30 & Passable \\
I_AD & 28.56 & 1.40 & Poor \\
\hline
\end{tabular}

Ambient-dried samples had higher values of the Carr index and Hausner ratio compared to the spray-dried PECs. The flowability of ambient-dried PECs based on these values was characterized as poor, while the flowability of spray-dried PECs was slightly better and characterized as passable. The entrapment of ibuprofen did not significantly affect the flow of PECs. The irregular shape of ambient-dried PEC particles can be the cause of their lower flowability. Resistance to the free flow can also occur due to cohesion between particles, which can result from electrostatic interactions caused by the potentially present free charge of polymers (46). The shape of the particles closer to spherical and lower residual moisture content in spray-dried PECs could cause the better flow of these powders $(47,48)$.

\section{Differential scanning calorimetry (DSC), Fourier-transform infrared spectroscopy (FTIR) and Powder X-ray diffraction (PXRD) analyses}

Figure 2 shows DSC thermograms, FT-IR spectra, and PXRD diffractograms of spray-dried and ambient-dried placebo PECs ( $\mathrm{P}_{-} \mathrm{SD}$ and $\left.\mathrm{P}_{-} \mathrm{AD}\right)$, their physical mixtures with ibuprofen at 1:1 mass ratio $\left(\mathrm{P}_{-} \mathrm{SD}+\mathrm{ibu}\right.$ and $\left.\mathrm{P}_{-} \mathrm{AD}+\mathrm{ibu}\right)$, and spray-dried ibuprofenloaded PEC (I_SD). 
A)

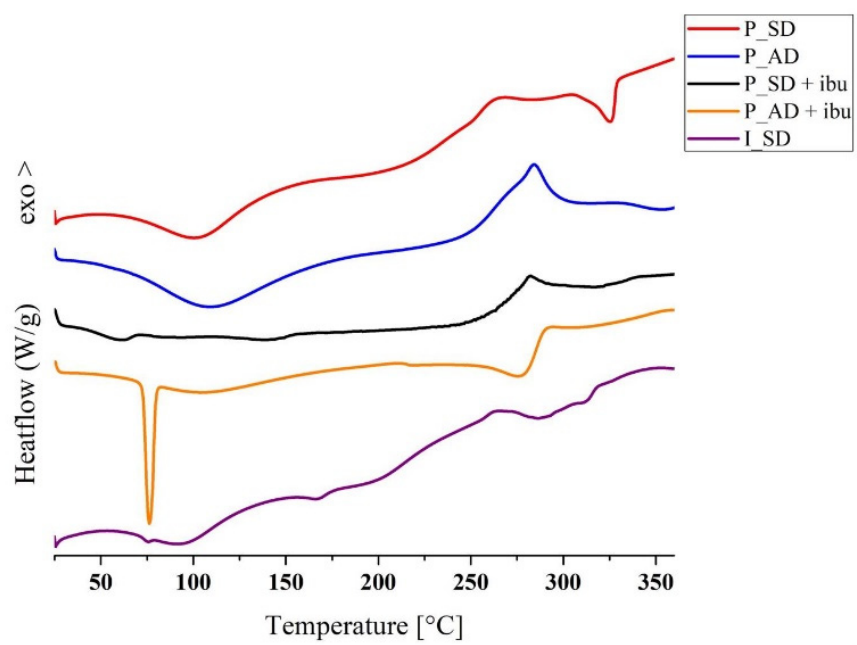

B)

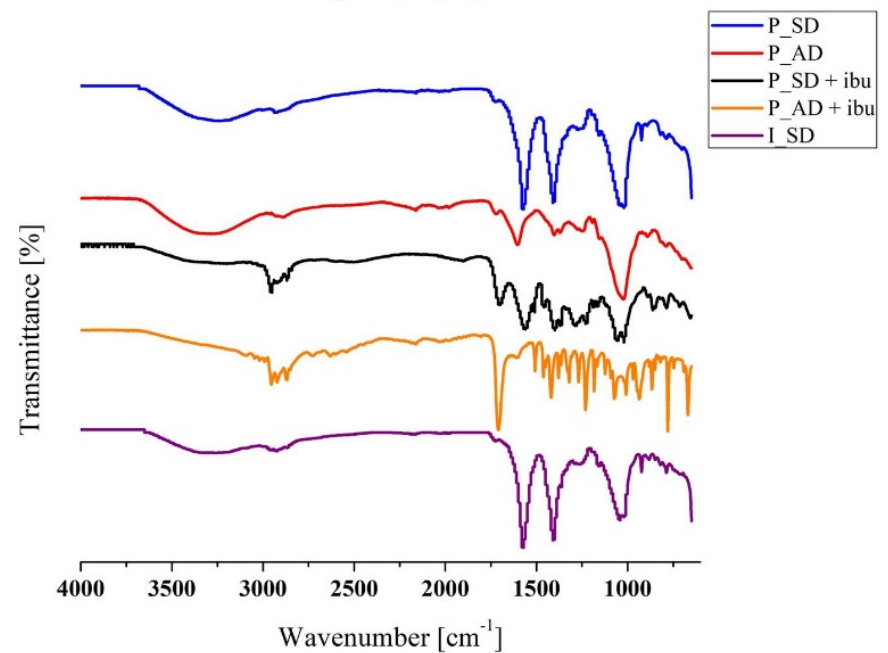

C)

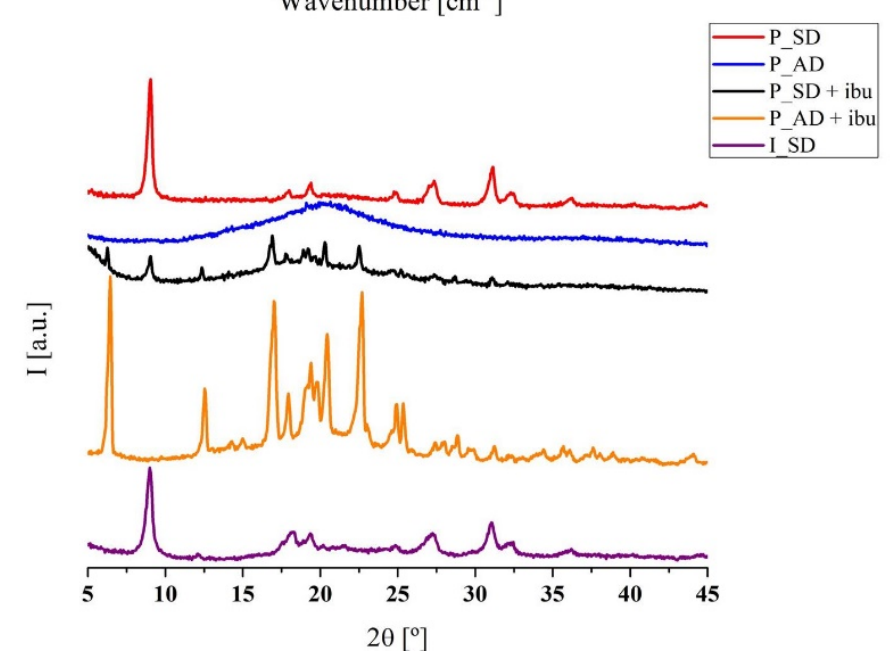

Figure 2. DSC thermograms (A), FT-IR spectra (B), and PXRD diffractograms (C) of spray-dried and ambient-dried placebo and ibuprofen-loaded PECs.

Slika 2. DSC termogrami (A), FT-IR spektri (B) i PXRD difraktogrami (C) suvih placebo PEK i PEK sa ibuprofenom dobijenih sušenjem raspršivanjem $i$ sušenjem pod ambijentalnim uslovima. 
As shown in Figure 2A, significant differences in DSC thermograms between ambient-dried and spray-dried samples can be noticed, as well as between placebo and ibuprofen-loaded PECs. Both placebo PECs (P_AD and P_SD) had wide endothermic peaks at approximately $100{ }^{\circ} \mathrm{C}$, at $109.61{ }^{\circ} \mathrm{C}$ for $\mathrm{P} \_\mathrm{AD}$ (onset at $55.45{ }^{\circ} \mathrm{C}$ and endset at $175.10{ }^{\circ} \mathrm{C}$ ) and $102.41{ }^{\circ} \mathrm{C}$ for P_SD (onset at $60.42{ }^{\circ} \mathrm{C}$ and endset at $139.40{ }^{\circ} \mathrm{C}$ ). These peaks were attributed to water/residual moisture evaporation (10). Besides, enthalpies of this process were in accordance with the residual moisture content of each placebo PEC, i.e., higher enthalpy value had $\mathrm{P}_{-} \mathrm{AD}(393.51 \mathrm{~J} / \mathrm{g})$ in comparison with $\mathrm{P}_{-} \mathrm{SD}(188.01 \mathrm{~J} / \mathrm{g})$. Ibuprofen-loaded PECs (I_AD and I_SD) showed notable differences in peaks corresponding to the active substance. As reported in our previous research, I_AD had a sharp endothermic peak at $76.01{ }^{\circ} \mathrm{C}$ (onset at $72.82{ }^{\circ} \mathrm{C}$ and endset at $81.59{ }^{\circ} \mathrm{C}$ ) (15) due to melting of crystalline ibuprofen, although the value was slightly shifted to lower temperature in comparison with pure ibuprofen, which was explained by the partial disruption of its crystal lattice $(15,34)$. On the thermogram of I_SD, the sharp peak was absent, but a wide peak corresponding to water/residual moisture evaporation at $94.46^{\circ} \mathrm{C}$ (onset at $55.45{ }^{\circ} \mathrm{C}$ and endset at $175.10^{\circ} \mathrm{C}$ ) can be clearly visualized. The absence of a peak related to melting of ibuprofen was proof of its amorphization during the spraydrying process (33), which was also confirmed by the PXRD analysis. On the other hand, spray-dried PECs (P_SD and I_SD) were semi-crystalline (PXRD analysis) and showed wide endothermic peaks at temperatures above $250{ }^{\circ} \mathrm{C}$ (at $325.84{ }^{\circ} \mathrm{C}$ for P_SD and at $289.90^{\circ} \mathrm{C}$ for I_SD) which were attributed to the melting of semi-crystalline xanthan gum $(10,49,50)$ with melting point around $270{ }^{\circ} \mathrm{C}(51)$.

FT-IR spectra of the investigated PECs are shown in Figure 2B. This study reconfirmed the formation of complexes between chitosan and xanthan gum (placebo PECs), as well as between chitosan, xanthan gum, and ibuprofen (ibuprofen-loaded PECs). Peaks characteristic for amines in the structure of chitosan around $1652 \mathrm{~cm}^{-1}, 1564$ $\mathrm{cm}^{-1}, 1374 \mathrm{~cm}^{-1}$, and $1312 \mathrm{~cm}^{-1}$, as well as for carbonyl stretching of carboxylate group of xanthan gum at $1604 \mathrm{~cm}^{-1}$ and $1402 \mathrm{~cm}^{-1}$ were absent in prepared PECs, proving the interaction establishment between polymers in complexes, as previously reported by many research groups $(10,52,53)$. Also, the peak correlated to carbonyl stretching of ibuprofen carboxylate group at approximately $1704 \mathrm{~cm}^{-1}(15,52,53)$, with minor shifting which was reported for I_AD (15) and physical mixtures of placebo PECs and ibuprofen, suggesting its presence in samples in the crystalline form. On the contrary, in I_SD this peak was absent, indicating the amorphization of the active substance, as also reported by Hussain et al. (52), which was confirmed by DSC and PXRD analysis. Besides, many investigations showed a negative correlation between peak intensity and interaction extent in samples $(10,15,52,53)$. Based on this fact, it can be concluded that interactions between polymers and ibuprofen were higher in ambient-dried in comparison with spraydried PECs. This result can be explained by the partial disruption of PEC integrity during homogenization and drying of these samples. In addition, the absence of new peaks in the formed PECs confirmed the supposition that the interactions between PEC components were exclusively physical (15). 
Figure 2C shows diffractograms of PECs obtained by the PXRD analysis. As expected based on our previous results (10), $\mathrm{P}_{-}$AD had an amorphous structure and its diffractogram consists of one wide peak with onset at $2 \theta$ of approximately $10^{\circ}$, endset at $30^{\circ}$, and maximum at $20.45^{\circ}$. For I_AD, the crystalline structure of ibuprofen was reported in our previous study (15). The diffractogram of I_AD showed many peaks between $5^{\circ}$ and $45^{\circ}$ characteristic for crystalline materials, with a maximum peak at $20.40^{\circ}$ (15). On the other hand, both P_SD and I_SD had semi-crystalline structures. Their diffractograms had few sharp peaks at approximately $9^{\circ}$ (maximum), $18^{\circ}, 19.5^{\circ}$, $25^{\circ}, 27.5^{\circ}, 31^{\circ}, 32.5^{\circ}$, and $36^{\circ}$. Since these values are present in both placebo and ibuprofen-loaded spray-dried PEC, it can be assumed that they were the consequence of the semi-crystalline structure of xanthan gum $(10,49,50)$, which was conserved during the spray-drying process, while ibuprofen dominantly lost its crystalline character (33). Our previous study (15), as well as the studies of other research groups (54), showed that ibuprofen had the peak of highest intensity at $2 \theta=16.00^{\circ}$ and other sharp peaks of high intensity at $2 \theta$ values of $6.25^{\circ}, 12.35^{\circ}, 17.80^{\circ}, 18.85^{\circ}, 19.15^{\circ}, 20.25^{\circ}$, and $22.45^{\circ}$. These $2 \theta$ values were not detected in I_SD, so we concluded that ibuprofen mostly lost its crystalline character during spray-drying of PEC. The solubility and dissolution rate of the drug can be increased by converting the crystalline form to the amorphous one, which is useful for poorly soluble drugs such as ibuprofen (24).

\section{Rehydration of dry PECs}

After $12 \mathrm{~h}$, complete rehydration of dry PECs was achieved in both media. Flow curves showed that all samples after rehydration had pseudoplastic flow with thixotropy (Figure 3). Table IV shows maximum (at $22.2 \mathrm{~s}^{-1}$ ) and minimum (at $100 \mathrm{~s}^{-1}$ ) apparent viscosities and hysteresis area $(\mathrm{H})$ values of dispersions obtained by rehydration of dry PECs dried by different methods in $0.1 \mathrm{M}$ hydrochloric acid ( $\mathrm{pH} 1.2)$ and phosphate buffer $\mathrm{pH} 7.4$. 
A)

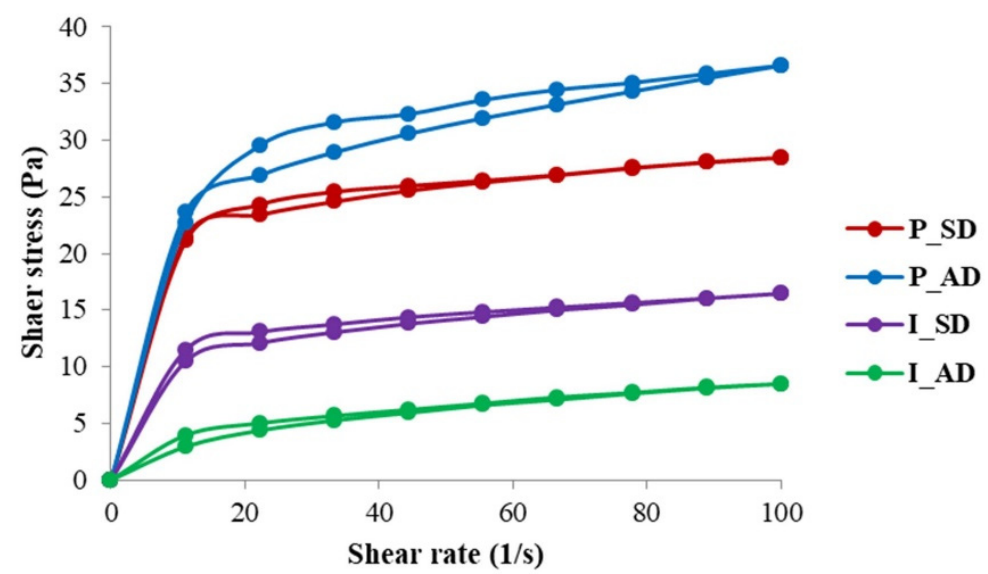

B)

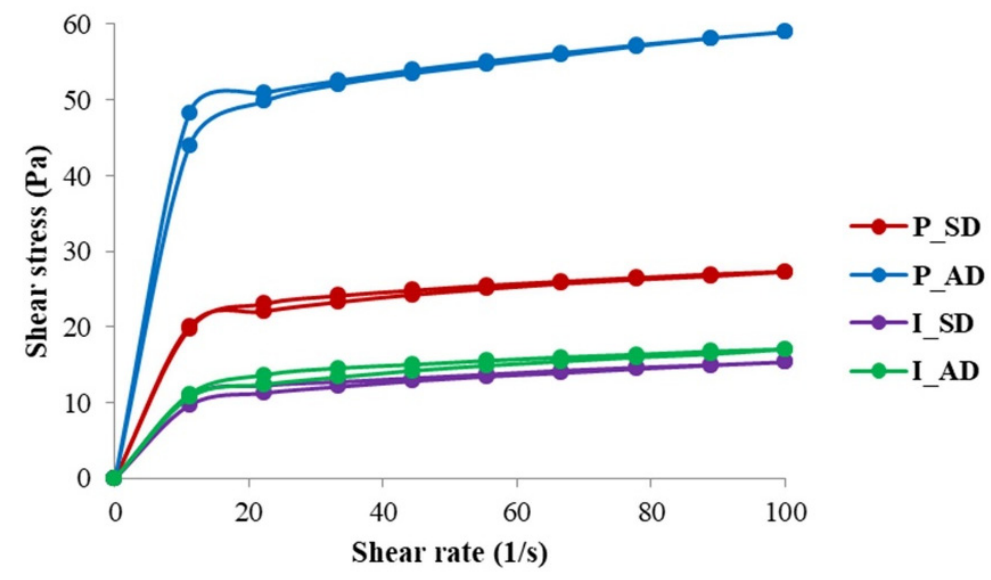

Figure 3. Flow curves of dispersions obtained by rehydration of spray-dried and ambient-dried placebo and ibuprofen-loaded PECs in (A) $0.1 \mathrm{M}$ hydrochloric acid (pH 1.2) and (B) phosphate buffer pH 7.4.

Slika 3. Krive proticanja disperzija dobijenih rehidratacijom suvih placebo PEK i PEK sa ibuprofenom dobijenih sušenjem raspršivanjem i sušenjem pod ambijentalnim uslovima u (A) 0,1 M hlorovodoničnoj kiselini (pH 1,2) i (B) fosfatnom puferu pH 7,4. 
Table IV Maximum apparent viscosity $\left(\eta_{\max }\right.$ at $\left.22.2 \mathrm{~s}^{-1}\right)$, minimum apparent viscosity $\left(\eta_{\min }\right.$ at $\left.100 \mathrm{~s}^{-1}\right)$, and $\mathrm{H}$ values for spray-dried and ambient-dried placebo and ibuprofen-loaded PECs rehydrated in 0.1 M hydrochloric acid ( $\mathrm{pH} 1.2)$ and phosphate buffer $\mathrm{pH} 7.4$.

Tabela IV Maksimalni prividni viskozitet $\left(\eta_{\max }\right.$ pri $\left.22,2 \mathrm{~s}^{-1}\right)$, minimalni prividni viskozitet $\left(\eta_{\min }\right.$ pri $\left.100 \mathrm{~s}^{-1}\right)$ i $\mathrm{H}$ vrednosti placebo PEK i PEK sa ibuprofenom dobijenih sušenjem raspršivanjem i sušenjem pod ambijentalnim uslovima nakon rehidratacije u 0,1 M hlorovodoničnoj kiselini ( $\mathrm{pH}$ 1,2) i fosfatnom puferu $\mathrm{pH} 7,4$.

\begin{tabular}{ccccccc}
\hline $\mathbf{p H}$ & $\mathbf{1 . 2}$ & & $\mathbf{7 . 4}$ & \\
\hline Sample & $\begin{array}{c}\boldsymbol{\eta}_{\max } \pm \boldsymbol{\sigma} \\
(\mathbf{P a} \cdot \mathbf{s})\end{array}$ & $\begin{array}{c}\boldsymbol{\eta}_{\min } \pm \boldsymbol{\sigma} \\
(\mathbf{P a} \cdot \mathbf{s})\end{array}$ & $\mathbf{H} \pm \boldsymbol{\sigma}(\mathbf{P a} / \mathbf{s})$ & $\begin{array}{c}\boldsymbol{\eta}_{\max } \pm \boldsymbol{\sigma} \\
(\mathbf{P a} \cdot \mathbf{s})\end{array}$ & $\begin{array}{c}\boldsymbol{\eta}_{\min } \pm \boldsymbol{\sigma} \\
(\mathbf{P a} \cdot \mathbf{s})\end{array}$ & $\mathbf{H} \pm \boldsymbol{\sigma}(\mathbf{P a} / \mathbf{s})$ \\
\hline P_SD & $1.09 \pm 0.07$ & $0.28 \pm 0.01$ & $43.96 \pm 12.11$ & $1.04 \pm 0.10$ & $0.27 \pm 0.02$ & $49.71 \pm 12.61$ \\
P_AD & $1.33 \pm 0.10$ & $0.37 \pm 0.03$ & $114.79 \pm 23.04$ & $2.24 \pm 0.29$ & $0.59 \pm 0.05$ & $300.99 \pm 81.74$ \\
I_SD & $0.59 \pm 0.02$ & $0.16 \pm 0.01$ & $54.87 \pm 24.74$ & $0.55 \pm 0.08$ & $0.15 \pm 0.02$ & $43.24 \pm 5.73$ \\
I_AD & $0.23 \pm 0.02$ & $0.08 \pm 0.01$ & $37.23 \pm 9.40$ & $0.61 \pm 0.10$ & $0.17 \pm 0.02$ & $81.11 \pm 25.96$ \\
\hline
\end{tabular}

The rehydration ability of the investigated PECs depended more on the $\mathrm{pH}$ of the medium than on the drying method, as can be seen from Table IV. Many research groups showed that the water-binding (rehydration or swelling) capacity of samples depends on the strength and extent of interactions between their constituents. Stronger and more extensive interactions hinder the penetration of the medium into PECs (55-57), which results in higher values of apparent viscosities. For ambient-dried PECs, higher apparent viscosities were measured after their rehydration in phosphate buffer $\mathrm{pH} 7.4$, while for spray-dried samples their apparent viscosities were similar after rehydration in both media. When comparing the placebo and ibuprofen-loaded PECs, ibuprofen-loaded PECs had lower apparent viscosities independent of the drying method. This result can be explained by the partial dissolution of active substance and consequently by partial disintegration of these samples, as previously reported (15). H values also followed this trend, so higher $\mathrm{H}$ values were noticed for placebo PECs.

\section{In vitro ibuprofen release}

The release profiles of ibuprofen from PECs dried by different methods are shown in Figure 4. 


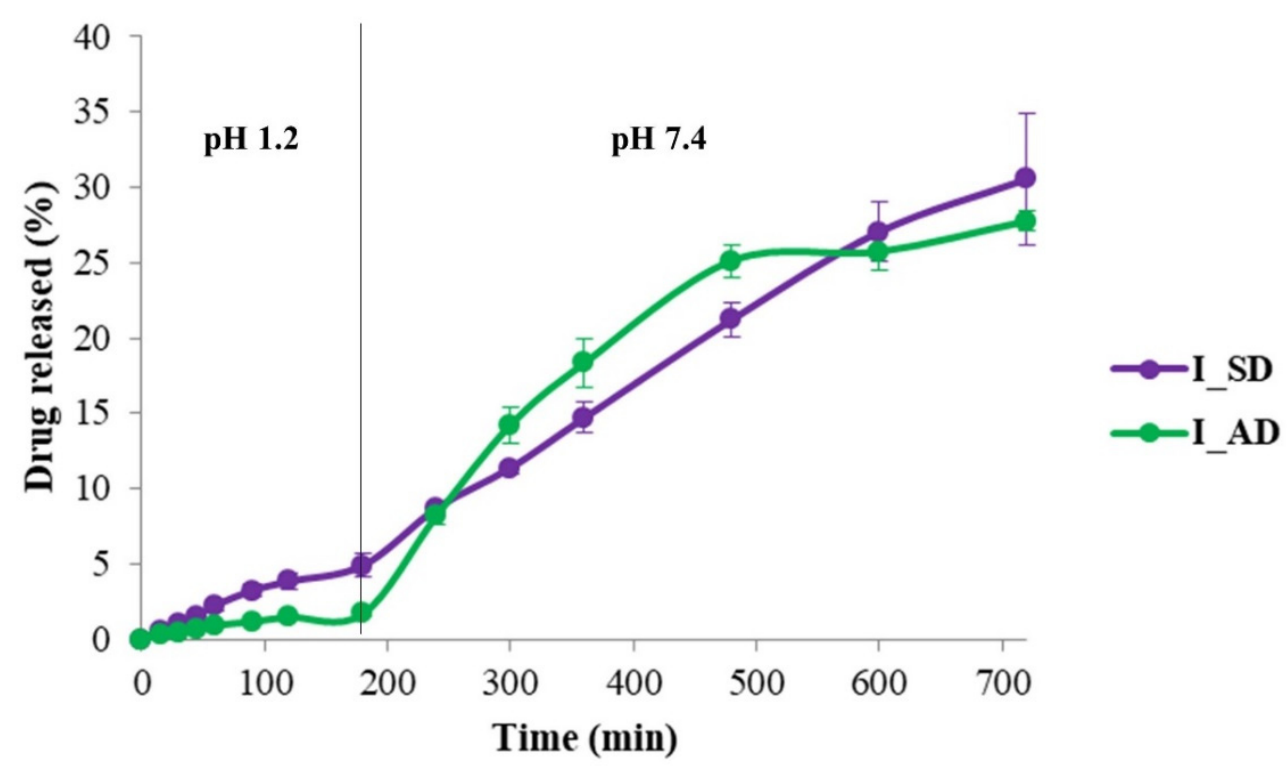

Figure 4. In vitro dissolution profiles of ibuprofen from spray-dried and ambientdried ibuprofen-loaded PECs.

Slika 4. In vitro profili oslobađanja ibuprofena iz PEK sa ibuprofenom dobijenih sušenjem raspršivanjem i sušenjem pod ambijentalnim uslovima.

Based on the drug release profiles, prolonged release of ibuprofen was achieved from PECs obtained by both drying methods. After $12 \mathrm{~h}, 27.76 \pm 0.65 \%$ of ibuprofen was released from I_AD, while from I_SD $30.55 \pm 4.36 \%$ of ibuprofen was released. Drug release was incomplete from both samples. As already mentioned, spray-drying can lead to the transition of the crystalline form of ibuprofen to the amorphous one, which has higher solubility, thus increasing the dissolution rate of ibuprofen $(23,33)$. However, differences between released amounts of drug from I_AD and I_SD after $12 \mathrm{~h}$ were negligible, suggesting that the ibuprofen release was not significantly influenced by its solubility. A slightly faster release of ibuprofen from I_SD was observed and can be related to the smaller particle size obtained by the spray-drying process, which increases the contact of the particles with dissolution media. The optimization of drying methods in order to improve the yield, drug entrapment efficiency, ibuprofen solubility, and/or the addition of excipients such as solubility enhancers in the formulation can lead to the improvement of ibuprofen dissolution rate from chitosan/xanthan gum PEC-based carriers. It is important to note that significant differences were also observed in the amount of drug released in media of different $\mathrm{pH}$ values. Significantly lower amounts of ibuprofen were released in $0.1 \mathrm{M}$ hydrochloric acid $(\mathrm{pH} 1.2)$ after $3 \mathrm{~h}(1.70 \%$ from I_AD and 4.91\% from I_SD) compared to the phosphate buffer $\mathrm{pH} 7.4$ (26.06\% from I_AD and $25.64 \%$ from I_SD) during $9 \mathrm{~h}$, following 3-hour drug release in $0.1 \mathrm{M}$ hydrochloric acid. For that reason, it can be concluded that the ibuprofen entrapment in the investigated 
PECs can result in both prolonged and delayed drug release. This is of particular importance due to the irritating potential of orally administered ibuprofen on the gastric mucosa (24). It can be concluded that, by its entrapment into chitosan/xanthan gum PECbased carriers, site-specific drug release in the small intestine can be achieved, which could reduce gastric irritation $(58,59)$.

The coefficients of determination $\left(\mathrm{R}^{2}\right)$ of the mathematical models describing the kinetics of ibuprofen release are shown in Table $\mathrm{V}$.

Table V Models of ibuprofen release kinetics with corresponding coefficients of determination $\left(\mathrm{R}^{2}\right)$ and Korsmeyer-Peppas diffusion exponents (n).

Tabela V Modeli kinetike oslobađanja ibuprofena sa odgovarajućim vrednostima koeficijenata determinacije $\left(\mathrm{R}^{2}\right)$ i vrednosti difuzionih eksponenata (n) za Korsmeyer-Peppas kinetički model.

\begin{tabular}{|c|c|c|c|c|c|}
\hline \multirow[b]{3}{*}{ Kinetics model } & \multirow[b]{3}{*}{$\begin{array}{c}\text { Part of dissolution } \\
\text { profile }\end{array}$} & \multirow{2}{*}{\multicolumn{2}{|c|}{$\mathbf{R}^{2}$}} & & \\
\hline & & & & & \\
\hline & & I_SD & I_AD & & \\
\hline \multirow{3}{*}{ zero-order } & complete profile & 0.9875 & 0.9311 & & \\
\hline & pH 1.2 & 0.9583 & 0.8962 & & \\
\hline & pH 7.4 & 0.9807 & 0.8490 & & \\
\hline \multirow{3}{*}{ first-order } & complete profile & 0.9763 & 0.9263 & & \\
\hline & pH 1.2 & 0.9628 & 0.8991 & & \\
\hline & pH 7.4 & 0.9581 & 0.8858 & & \\
\hline \multirow{3}{*}{ Higuchi } & complete profile & 0.7881 & 0.7360 & & \\
\hline & pH 1.2 & 0.9036 & 0.9375 & \multicolumn{2}{|c|}{$\mathbf{n}$} \\
\hline & pH 7.4 & 0.7073 & 0.7470 & I_SD & I_AD \\
\hline \multirow{3}{*}{$\begin{array}{l}\text { Korsmeyer- } \\
\text { Peppas }\end{array}$} & complete profile & 0.9933 & 0.9254 & 1.144 & 1.110 \\
\hline & pH 1.2 & 0.9788 & 0.9618 & 0.796 & 0.687 \\
\hline & pH 7.4 & 0.9855 & 0.8491 & 1.108 & 0.831 \\
\hline
\end{tabular}

Based on the calculated values of the coefficients of determination for complete profiles, it can be concluded that the release of ibuprofen from I_AD followed the zeroorder kinetics $\left(\mathrm{R}^{2}=0.9311\right)$, while the release from I_SD followed the Korsmeyer-Peppas kinetics $\left(\mathrm{R}^{2}=0.9933\right)$. However, the calculated coefficient of determination for zero-order kinetics for I_SD $\left(\mathrm{R}^{2}=0.9875\right)$ was also high, higher than the one calculated for I_AD. Therefore, it can be concluded that from both ibuprofen-loaded PECs, but especially from I_SD, ibuprofen was released at an almost constant rate during $12 \mathrm{~h}(0.038 \mathrm{mg} / \mathrm{min}$ from I_AD and $0.043 \mathrm{mg} / \mathrm{min}$ from I_SD). For I_SD, it was observed that the release of ibuprofen followed the Korsmeyer-Peppas release kinetics, regardless of the $\mathrm{pH}$ of the 
medium and the duration of the assay. On the other hand, from I_AD during the first $3 \mathrm{~h}$ in $0.1 \mathrm{M}$ hydrochloric acid the release of ibuprofen followed the Korsmeyer-Peppas kinetics, and during the next $9 \mathrm{~h}$ in phosphate buffer $\mathrm{pH} 7.4$ the first-order kinetics. Korsmeyer-Peppas kinetics model is typical for carriers having the ability to swell, such as xanthan gum and the combination of xanthan gum with other polymers, while the firstorder kinetics shows that the release rate of the drug depends on its concentration. The $n$ values for the Korsmeyer-Peppas kinetics model showed that the mechanism of ibuprofen release was a combination of its diffusion after the swelling of the carrier and relaxation of polymer chains and erosion (36).

The calculated value of the difference factor $\left(f_{l}\right)$ was 19.66 and the similarity factor $\left(f_{2}\right)$ was 80.57. Based on the obtained results, ibuprofen release profiles from PECs obtained by different drying methods can be considered similar if only $f_{2}$ is taken into account, while they would be considered different if both factors $\left(f_{1}\right.$ and $\left.f_{2}\right)$ were taken into account $(39,40)$.

\section{Conclusion}

When comparing ibuprofen-loaded PECs dried by different methods, a significantly lower yield, ibuprofen content, and entrapment efficiency in spray-dried samples compared to ambient-dried samples were shown. A higher proportion of finer particles could be observed in the spray-dried samples, while the ambient-dried samples were of a more irregular shape and larger particles. The shape of the particles closer to spherical in the spray-dried samples was the cause of their better flowability, which is favorable for the production of solid dosage forms such as capsules and tablets. DSC and PXRD analysis revealed a more pronounced change in the crystallinity of ibuprofen after spraydrying, while FT-IR analysis showed exclusively physical interactions in complexes. All the investigated PECs had good rehydration ability in media of different $\mathrm{pH}$ values. The release profiles of ibuprofen from hard capsules filled with ibuprofen-loaded PECs showed a constant drug release rate during $12 \mathrm{~h}$, with approximately $30 \%$ of ibuprofen released, but with a tendency for further release over a longer period. Moreover, ibuprofen dissolution rate can be improved by the optimization of drying methods and the addition of excipients such as solubility enhancers in the formulations. Both drying methods can provide the production of PECs with the prolonged and $\mathrm{pH}$-dependent release of ibuprofen, which can contribute to reducing the frequency of dosing (e.g., once or twice a day), lowering gastric irritation, and increasing patient acceptance. In addition, a difference was observed in the mechanisms that control the diffusion of the active substance from the carriers obtained by different drying procedures. Better diffusion control was achieved with spray-dried PEC because higher linearity was observed, i.e., a higher value of the coefficient of determination for zero-order kinetics indicating the release of ibuprofen at a constant rate. Although ambient drying could be considered a better drying process in this case due to a higher yield, entrapment efficiency, and better control of $\mathrm{pH}$-dependent ibuprofen release, spray-drying is a more convenient method for systems with lower strength and extent of intermolecular interactions. Moreover, after the 
optimization of the spray-drying method parameters, it could be acceptable for the industrial production of PEC-based drug carriers of high yield, entrapment efficiency, and ability to achieve complete, sustained, and delayed release of ibuprofen, which requires further research.

\section{Acknowledgement}

The authors would like to thank Zorica Drašković and Slobodan Tanasin for their assistance in the preparation of the investigated PECs. The authors are also thankful to Galenika a.d. (Belgrade, Serbia), and Inexall Company d.o.o. (Subotica, Serbia) for providing the gift samples of ibuprofen and xanthan gum, respectively.

This work was supported by the Ministry of Education, Science and Technological Development of the Republic of Serbia (Number 451-03-9/2021-14/200161).

\section{References}

1. Savjani KT, Gajjar AK, Savjani JK. Drug Solubility: Importance and Enhancement Techniques. ISRN Pharm. 2012;2012:1-10.

2. Meka VS, Sing MKG, Pichika MR, Nali SR, Kolapalli VRM, Kesharwani P. A comprehensive review on polyelectrolyte complexes. Drug Discov Today. 2017;22(11):1697-706.

3. Berger J, Reist M, Mayer JM, Felt O, Gurny R. Structure and interactions in chitosan hydrogels formed by complexation or aggregation for biomedical applications. Eur J Pharm Biopharm. 2004;57(1):35-52.

4. Berger J, Reist M, Mayer JM, Felt O, Peppas NA, Gurny R. Structure and interactions in covalently and ionically crosslinked chitosan hydrogels for biomedical applications. Eur J Pharm Biopharm. 2004;57(1):19-34.

5. Ćirić A, Krajišnik D, Čalija B, Đekić L. Biocompatible non-covalent complexes of chitosan and different polymers: Characteristics and application in drug delivery. Arh Farm (Belgr). 2020;70(4):173-97.

6. Bigucci F, Luppi B, Cerchiara T, Sorrenti M, Bettinetti G, Rodriguez L, et al. Chitosan/pectin polyelectrolyte complexes: Selection of suitable preparative conditions for colon-specific delivery of vancomycin. Eur J Pharm Sci. 2008;35(5):435-41.

7. Bhattarai N, Gunn J, Zhang M. Chitosan-based hydrogels for controlled, localized drug delivery. Adv Drug Deliv Rev. 2010;62(1):83-99.

8. Naidu VGM, Madhusudhana K, Sashidhar RB, Ramakrishna S, Khar RK, Ahmed FJ, et al. Polyelectrolyte complexes of gum kondagogu and chitosan, as diclofenac carriers. Carbohydr Polym. 2009;76(3):464-71.

9. Maurstad G, Kitamura S, Stokke BT. Isothermal titration calorimetry study of the polyelectrolyte complexation of xanthan and chitosan samples of different degree of polymerization. Biopolymers. 2012;97(1):1-10.

10. Ćirić A, Medarević, Čalija B, Dobričić V, Mitrić M, Djekic L, et al. Study of chitosan/xanthan gum polyelectrolyte complexes formation, solid state and influence on ibuprofen release kinetics. Int $\mathrm{J}$ Biol Macromol. 2020;148:942-55. 
11. Toniazzo T, Berbel IF, Cho S, Fávaro-Trindade CS, Moraes ICF, Pinho SC. $\beta$-carotene-loaded liposome dispersions stabilized with xanthan and guar gums: Physico-chemical stability and feasibility of application in yogurt. LWT - Food Sci Technol. 2014;59(2P2):1265-73.

12. Petri DFS. Xanthan gum: A versatile biopolymer for biomedical and technological applications. J Appl Polym Sci. 2015;132(23):42035.

13. Moin A, Shivakumar H, Deb T, Ramireddy B. In vitro-in vivo evaluation of xanthan gum and eudragit inter polyelectrolyte complex based sustained release tablets. Int J Pharm Investig. 2015;5(1):65-72.

14. Argin-Soysal S, Kofinas P, Lo YM. Effect of complexation conditions on xanthan-chitosan polyelectrolyte complex gels. Food Hydrocoll. 2009;23:202-9.

15. Ćirić A, Medarević Đ, Čalija B, Dobričić V, Rmandić M, Barudžija T, et al. Effect of ibuprofen entrapment procedure on physicochemical and controlled drug release performances of chitosan/xanthan gum polyelectrolyte complexes. Int J Biol Macromol. 2021;167:547-58.

16. Hamman JH. Chitosan based polyelectrolyte complexes as potential carrier materials in drug delivery systems. Mar Drugs. 2010;8(4):1305-22.

17. Bourganis V, Karamanidou T, Kammona O, Kiparissides C. Polyelectrolyte complexes as prospective carriers for the oral delivery of protein therapeutics. Eur J Pharm Biopharm. 2017;111:44-60.

18. Cerchiara T, Abruzzo A, Parolin C, Vitali B, Bigucci F, Gallucci MC, et al. Microparticles based on chitosan/carboxymethylcellulose polyelectrolyte complexes for colon delivery of vancomycin. Carbohydr Polym. 2016;143:124-30.

19. Bigucci F, Abruzzo A, Vitali B, Saladini B, Cerchiara T, Gallucci MC, et al. Vaginal inserts based on chitosan and carboxymethylcellulose complexes for local delivery of chlorhexidine: Preparation, characterization and antimicrobial activity. Int J Pharm. 2015;478(2):456-63.

20. Čalija B, Savic S, Krajišnik D, Daniels R, Vučen S, Markovic B, et al. PH-sensitive polyelectrolyte films derived from submicron chitosan/Eudragit ${ }^{\circledR}$ L 100-55 complexes: Physicochemical characterization and in vitro drug release. J Appl Polym Sci. 2015;132(39):1-9.

21. Hu Q, Wang T, Zhou M, Xue J, Luo Y. Formation of redispersible polyelectrolyte complex nanoparticles from gallic acid-chitosan conjugate and gum arabic. Int $\mathrm{J}$ Biol Macromol. 2016;92:812-9.

22. Dimer FA, Ortiz M, Pohlmann AR, Guterres SS. Inhalable resveratrol microparticles produced by vibrational atomization spray drying for treating pulmonary arterial hypertension. J Drug Deliv Sci Technol. 2015;29:152-8.

23. Mishra B, Mishra M, Yadav SK. Antibacterial loaded spray dried chitosan polyelectrolyte complexes as dry powder aerosol for the treatment of lung infections. Iran J Pharm Res. 2017;16(1):74-92.

24. Irvine J, Afrose A, Islam N. Formulation and delivery strategies of ibuprofen: challenges and opportunities. Drug Dev Ind Pharm. 2018;44(2):173-83.

25. Wong TW, Chan LW, Kho S Bin, Sia Heng PW. Design of controlled-release solid dosage forms of alginate and chitosan using microwave. J Control Release. 2002;84(3):99-114.

26. Das S, Ng KY, Ho PC. Formulation and optimization of zinc-pectinate beads for the controlled delivery of resveratrol. AAPS PharmSciTech. 2010;11(2):729-42. 
27. Das S, Ng KY. Colon-specific delivery of resveratrol: Optimization of multi-particulate calciumpectinate carrier. Int J Pharm. 2010;385(1-2):20-8.

28. Das S, Chaudhury A, Ng KY. Preparation and evaluation of zinc-pectin-chitosan composite particles for drug delivery to the colon: Role of chitosan in modifying in vitro and in vivo drug release. Int $\mathbf{J}$ Pharm. 2011;406(1-2):11-20.

29. Patel B, Patel J, Chakraborty S. Review of Patents and Application of Spray Drying in Pharmaceutical, Food and Flavor Industry. Recent Pat Drug Deliv Formul. 2014;8(1):63-78.

30. Pontip B, Suchada P, Sriamornsak P. Effect of formulations and spray drying process conditions on physical properties of resveratrol spray-dried emulsions. Key Eng Mater. 2019;819:246-51.

31. Caddeo C, Nácher A, Díez-Sales O, Merino-Sanjuán M, Fadda AM, Manconi M. Chitosan-xanthan gum microparticle-based oral tablet for colon-targeted and sustained delivery of quercetin. J Microencapsul. 2014;31(7):694-9.

32. Potthast H, Dressman JB, Junginger HE, Midha KK, Oeser H, Shah VP, et al. Biowaiver monographs for immediate release solid oral dosage forms: Ibuprofen. J Pharm Sci. 2005;94(10):2121-31.

33. Elkordya AA, Essa EA. Effects of spray drying and spray chilling on ibuprofen dissolution. Iran J Pharm Sci. 2010;6(1):3-12.

34. Sogias IA, Williams AC, Khutoryanskiy V V. Chitosan-based mucoadhesive tablets for oral delivery of ibuprofen. Int J Pharm. 2012;436(1-2):602-10.

35. Laracuente ML, Yu MH, McHugh KJ. Zero-order drug delivery: State of the art and future prospects. J Control Release. 2020;327:834-56.

36. Salome AC, Godswill CO, Ikechukwu IO. Kinetics and mechanisms of drug release from swellable and non swellable matrices: A review. Res J Pharm Biol Chem Sci. 2013;4(2):97-103.

37. Siepmann J, Peppas NA. Higuchi equation: Derivation, applications, use and misuse. Int J Pharm. 2011;418(1):6-12.

38. Wu IY, Bala S, Škalko-Basnet N, di Cagno MP. Interpreting non-linear drug diffusion data: Utilizing Korsmeyer-Peppas model to study drug release from liposomes. Eur J Pharm Sci. 2019;138:105026.

39. Zhang Y, Huo M, Zhou J, Zou A, Li W, Yao C, et al. DDSolver: An add-in program for modeling and comparison of drug dissolution profiles. AAPS J. 2010;12(3):263-71.

40. Diaz DA, Colgan ST, Langer CS, Bandi NT, Likar MD, Van Alstine L. Dissolution Similarity Requirements: How Similar or Dissimilar Are the Global Regulatory Expectations? AAPS J. 2016;18(1):15-22.

41. Ceschan NE, Bucalá V, Mateos MV, Smyth HDC, Ramírez-Rigo MV. Carrier free indomethacin microparticles for dry powder inhalation. Int J Pharm. 2018;549(1-2):169-78.

42. Dima C, Pətraşcu L, Cantaragiu A, Alexe P, Dima Ş. The kinetics of the swelling process and the release mechanisms of Coriandrum sativum L. essential oil from chitosan/alginate/inulin microcapsules. Food Chem. 2016;195:39-48.

43. Mladenovska K, Raicki RS, Janevik EI, Ristoski T, Pavlova MJ, Kavrakovski Z, et al. Colon-specific delivery of 5-aminosalicylic acid from chitosan-Ca-alginate microparticles. Int $\mathrm{J}$ Pharm. 2007;342(1-2):124-36.

44. Ding B, Li C, Pan M, Chiou Y, Li Z, Wei S, et al. Microencapsulation of xanthan gum based on palm stearin/beeswax matrix as wall system. J Food Process Eng. 2019;42(5):e13102. 
45. Budinčić JM, Petrović L, Đekić L, Fraj J, Bučko S, Katona J, et al. Study of vitamin E microencapsulation and controlled release from chitosan/sodium lauryl ether sulfate microcapsules. Carbohydr Polym. 2021;251:116988.

46. Lee BJ. Pharmaceutical preformulation: physicochemical properties of excipients and powders and tablet characterization. In: Gad SC, editor, Pharmaceutical Manufacturing Handbook: Production and Processes. Hoboken, New Jersey: John Wiley \& Sons, Inc.; 2008; p. 905-9.

47. Chomto P, Nunthanid J. Physicochemical and powder characteristics of various citrus pectins and their application for oral pharmaceutical tablets. Carbohydr Polym. 2017;174:25-31.

48. Crouter A, Briens L. The effect of moisture on the flowability of pharmaceutical excipients. AAPS PharmSciTech. 2014;15(1):65-74.

49. Elizalde-Peña EA, Zarate-Triviño DG, Nuño-Donlucas SM, Medina-Torres L, Gough JE, Sanchez IC, et al. Synthesis and characterization of a hybrid (chitosan-g-glycidyl methacrylate)-xanthan hydrogel. J Biomater Sci Polym Ed. 2013;24(12):1426-42.

50. Thakur A, Monga S, Wanchoo RK. Sorption and drug release studies from semi-interpenetrating polymer networks of Chitosan and Xanthan Gum. Chem Biochem Eng Q. 2014;28(1):105-15.

51. Rowe RC, Sheskey PJ, Quinn ME, editors. Handbook of Pharmaceutical Excipients. 6th ed. London: Pharmaceutical Press; 2009. 783 p.

52. Hussain A, Smith G, Khan KA, Bukhari NI, Pedge NI, Ermolina I. Solubility and dissolution rate enhancement of ibuprofen by co-milling with polymeric excipients. Eur J Pharm Sci. 2018;123:395-403.

53. Abioye AO, Armitage R, Kola-Mustapha AT. Thermodynamic Changes Induced by Intermolecular Interaction between Ibuprofen and Chitosan: Effect on Crystal Habit, Solubility and in Vitro Release Kinetics of Ibuprofen. Pharm Res. 2016;33(2):337-57.

54. Wikarsa S, Durand D, Delarbre JL, Baylac G, Bataille B. The improvement of ibuprofen dissolution rate through microparticles spray drying processed in an aqueous system. Drug Dev Ind Pharm. 2008;34(5):485-91.

55. Lv X, Zhang W, Liu Y, Zhao Y, Zhang J, Hou M. Hygroscopicity modulation of hydrogels based on carboxymethyl chitosan/Alginate polyelectrolyte complexes and its application as $\mathrm{pH}$-sensitive delivery system. Carbohydr Polym. 2018;198:86-93.

56. Nath SD, Abueva C, Kim B, Lee BT. Chitosan-hyaluronic acid polyelectrolyte complex scaffold crosslinked with genipin for immobilization and controlled release of BMP-2. Carbohydr Polym. 2015;115:160-9.

57. Chen Y, Yan X, Zhao J, Feng H, Li P, Tong Z, et al. Preparation of the chitosan/poly(glutamic acid)/alginate polyelectrolyte complexing hydrogel and study on its drug releasing property. Carbohydr Polym. 2018;191:8-16.

58. Shang Q, Huang S, Zhang A, Feng J, Yang S. The binary complex of poly(PEGMA-co-MAA) hydrogel and PLGA nanoparticles as a novel oral drug delivery system for ibuprofen delivery. $\mathrm{J}$ Biomater Sci Polym Ed. 2017;28(16):1874-87.

59. Ofokansi KC, Kenechukwu FC. Formulation Development and Evaluation of Drug Release Kinetics from Colon-Targeted Ibuprofen Tablets Based on Eudragit RL 100-Chitosan Interpolyelectrolyte Complexes. ISRN Pharm. 2013;2013:1-8. 


\title{
Uticaj postupka sušenja raspršivanjem na svojstva polielektrolitnih kompleksa hitozana i ksantan gume kao nosača za peroralnu isporuku ibuprofena
}

\author{
Ana Ćirić $^{1 *}$, Jelena Milinković Budinčić2 , Đorđe Medarevićc ${ }^{1}$, \\ Vladimir Dobričić ${ }^{3}$, Milena Rmandić ${ }^{4}$, Tanja Barudžija ${ }^{5}$, \\ Anđelija Malenovićc ${ }^{4}$ Lidija Petrović $^{2}$, Ljiljana Đekić ${ }^{1}$
}
${ }^{1}$ Univerzitet u Beogradu - Farmaceutski fakultet, Katedra za farmaceutsku tehnologiju i kozmetologiju, Vojvode Stepe 450, 11221 Beograd, Srbija
${ }^{2}$ Univerzitet u Novom Sadu - Tehnološki fakultet, Katedra za biotehnologiju i farmaceutsko inženjerstvo, Bulevar cara Lazara 1, 21102 Novi Sad, Srbija
${ }^{3}$ Univerzitet u Beogradu - Farmaceutski fakultet, Katedra za farmaceutsku hemiju, Vojvode Stepe 450, 11221 Beograd, Srbija
${ }^{4}$ Univerzitet u Beogradu - Farmaceutski fakultet, Katedra za analitiku lekova, Vojvode Stepe 450, 11221 Beograd, Srbija
${ }^{5}$ Univerzitet u Beogradu, Institut za nuklearne nauke „Vinča“, Laboratorija za teorijsku fiziku i fiziku kondenzovane materije, Mike Petrovića Alasa 12-14, 11351 Beograd, Srbija

*Autor za korespondenciju: Ana Ćirić, e-mail: ana.ciric@pharmacy.bg.ac.rs

\begin{abstract}
Kratak sadržaj
Polielektrolitni kompleksi (PEK) su atraktivni nosači sa potencijalom poboljšanja peroralne isporuke slabo rastvorljivih visokodoziranih lekovitih supstanci niske molekulske mase. Formulisanje čvrstih oralnih farmaceutskih oblika na bazi PEK zahteva njihovo sušenje, što može uticati na fizičko-hemijska i biofarmaceutska svojstva kompleksa. Cilj ove studije bio je da se ispita efekat sušenja raspršivanjem na svojstva PEK hitozana i ksantan gume u koje je inkorporiran ibuprofen i da se proceni kinetika oslobađanja lekovite supstance iz takvih PEK napunjenih u tvrde kapsule u poređenju sa odgovarajućim PEK koji su sušeni pod ambijentalnim uslovima. Prinos, sadržaj ibuprofena, efikasnost inkorporiranja i sadržaj vlage PEK sušenih raspršivanjem bili su niži nego kod PEK sušenih pod ambijentalnim uslovima. Bolja protočnost PEK osušenih raspršivanjem je posledica skoro sfernog oblika čestica, što je pokazano skenirajućom elektronskom mikroskopijom. Rezultati DSC i PXRD analiza su potvrdili amorfizaciju ibuprofena tokom sušenja raspršivanjem. Ispitivani PEK osušeni pod različitim uslovima imali su visoku sposobnost rehidratacije u 0,1 M hlorovodoničnoj kiselini ( $\mathrm{pH} 1,2)$ i fosfatnom puferu $\mathrm{pH}$ 7,4. In vitro oslobađanje ibuprofena iz osušenih PEK bilo je kontrolisano tokom $12 \mathrm{~h}$ uz oslobađanje približno 30\% inkorporiranog ibuprofena. PEK sušeni raspršivanjem obezbedili su bolju kontrolu difuzije ibuprofena iz nosača u poređenju sa onima sušenim pod ambijentalnim uslovima.
\end{abstract}

Ključne reči: hitozan, ksantan guma, ibuprofen, sušenje raspršivanjem, kontrolisano oslobađanje 